by seventy electrical engineers, of whom twelve came from universities and electrical undertakings abroad. In his opening address Colonel B. H. Leeson, director of the British Electrical Manufacturers' Association, referred to the importance of periodically taking stock of progress, and of preparing a co-ordinated plan for further development and research. Mr, F, J, Lane, of the British Electricity Authority, considered practical problems to be faced in developing a power system, and this was followed by a review of practical methods for performing network calculation by $\mathrm{Mr}$. C. H. Lackey, of Messrs. A. Reyrolle. The latest analytical methods for the determination of the circuit parameters of overhead lines, underground cables, transformers and loads were reviewed by Mr. L. A. Gosland, of the Electrical Research Association ; and Dr. J. R. Mortlock, of the British ThomsonHouston Co., Ltd., discussed the theories used in determining equivalent circuits for alternators. A review of the most useful methods of determining the steady-state and transient power limits of networks was given by Mr. G. W. B. Mitchell, of Messrs. Merz and McLellan, and this was followed by a visit to the A.C. network analyser of Associated Electrical Industries at Willesden. A lecture on methods of solving complex simultaneous equations by Mr. M. W. Humphrey Davies, of the Imperial College, advocated greater use of computing machines for the simpler problems in system engineering work. Finally, Mr. F. J. Lane discussed the effect of some of the economic and technical considerations which it had not been possible to include in the course. In concluding, Prof. Willis Jackson stressed the need for increased co-operation between the universities, the technical colleges and industry to ensure wider dissemination and better utilization of the results of research already performed, and to stimulate the development of improved methods of analysis.

\section{American Pectoral Sandpipers in Britain}

IN the autumn of 1948 a miniature invasion of American pectd sandpipers (Calidris melanotos) occurred injwat Britain. Birds were recorded in nine differ localities including Scotland, Cornwall and Heast and west Midlands (British Birds, 42, No. 5 May 1949). It is difficult to state whether the immigration was due to anything unusual in whd or other conditions because of the scattered nature of the occurrences both regarding date and place. The pectoral sandpiper breeds in north-eastern Siberia as well as in arctic America and has been met with, though not positively proved to breed, as far west as the Taimyr Peninsula. The Taimyr is the nearest regular breeding ground of the knot (Calidris canutus), which visits Western Europe in great numbers, and this has raised the question whether some of the pectoral sandpipers visiting the British Isles may not come from Siberia rather than across the Atlantic from America. That some do come from America is suggested by the fact that half of the records from the west of England come from the Scilly Isles; this conclusion is strongly reinforced by the several occurrences in the west of Ireland and the virtual absence of records from the Continent. The supposition that some of the visitors come from Siberia is supported by the fact that there are about twice as many records for the eastern part of England as for the west.

\section{Scottish Needs ip/Building Research}

THE Scottisb Laboratory of the Building Research Station, whifh is at Thorntonhall, near Glasgow, is now party completed, and a nucleus of staff has begun york there. In connexion with this, a one-day confence on "Scottish Needs in Building Research" is to be held on October 6 in the Rankine Hall of the Institution of Engineers and Shipbuilders in Scotland, 39 Elmbank Crescent, Glasgow, C.2. Apart from imtroducing the new Laboratory, the purpose of the conference is to provide a forum from which Scottish members of the building industry can express their views on Scottish building problems which need research. Admission will be by ticket, and further details can be obtained from the Director, Building Research Station, Garston, Watford, Herts.

\section{Conference at Edinburgh on Elementary Particles}

Prof. Niels Eo/ will deliver the Gifford Lectures at the University of Edinburgh on Mondays, Wednesdays and Pridays, October 21-November 11, his subject being "Causality and Complementarity". Following/this a conference on elementary particles will be/held in the Natural Philosophy Buildings, Univgrsity, Drummond Street, Edinburgh, during Noyember 14-16. Talks so far arranged are as fglows: Prof. W. Heisenberg, "Die Erzeugung von Mesonen in Vielfachprozessen"; Prof. L. Jánossy, "On the Production of Mesons by Nucleons"; Prof. H. A. Kramers, "Quantum Electrodynamics and Correspondence-Principle" ; Dr. B. Pontecorvo, "On the Decay Products of the $\mu$-Meson"; Dr. J. G. Wilson, "Some New Measurements on the Nature of the Vertical Cosmic-Ray Beam at Sea Level"; Prof. M. Born, "General Theory of Elementary Particles" ; Prof. N. Feather, "Experimental Evidence concerning the Possible Existence of the Negative Proton and the Di-Neutron"; Dr. K. C. Cheng, "Reciprocity Theory of Electrodynamics". Other participants will include Profs. F. Bopp, M. Fierz, L. Leprince-Ringuet, C. Møller, C. F. Powell, A. Proca and Dr. H. O. W. Richardson. All interested may attend and should inform Mr. A. Nisbet, Department of Mathematical Physics, University, Drum. mond Street, Edinburgh 8, who will assist in finding accommodation on request.

\section{Colonial Service; Recent Appointments}

THE following appointments in the Colonial Service have been relently announced. G. F. Godden, agricultural offcer, Nyasaland; R. G. Hampson, agricultural ffficer, Uganda; L. J. C. Wells, agricultural officer Kenya; D. W. G. Bacon, assistant conservator of folests, Uganda; C. O. Baker, geologist, Sierra Leone; J. W. Barnes, geologist, Uganda ; E. F. Bradford, geologist, Federation of Malaya; J. F. Feakes, geologist, Gold Coast ; N. S. Haile, geologist, Sarawak; W. N. MacLeod, geologist, Nigeria; D. Magraw, geologist, Kenya ; M. G. D. Rees, geologist, Kenya; E. P. Saggerson, geologist, Kenya; J. Spence, geologist, Tanganyika; G. E. Wilford, geologist, Sarawak ; J. R. Gibbs, veterinary officer, Uganda; J. A. C. Stewart, veterinary officer, Tanganyika; W. C. Davies, meteorologist, East African High Commission; T. M. Greenshill, agricultural development officer, Nigeria; D. J. Moorhead, veterinary officer, Tanganyika; A. L. Stwart, metallurgist, Geological Department, Kenya ; D. B. Turner, provincial tsetse officer, Tanganyika; J. O. Wadhams, assistant conservator of forests, Northern 